\title{
A Panel Data Analysis of Jordan's Foreign Trade: The Gravity Model Approach
}

\author{
Ziad Mohammed Abu-Lila ${ }^{1}$ \\ ${ }^{1}$ Economics of Finance and Business Department, Al Al-Bayt University, Mafraq, Jordan \\ Correspondence: Ziad Mohammed Abu-Lila, Economics of Finance and Business Department, Al Al-Bayt \\ University, Mafraq, Jordan. E-mail: abu-lila@yu.edu.jo
}

Received: November 15, 2017

Accepted: November 28, $2017 \quad$ Online Published: December 15, 2017

doi:10.5539/ijef.v10n1p204

URL: https://doi.org/10.5539/ijef.v10n1p204

\begin{abstract}
This study aims to identify the most important factors affecting the flow of Jordanian foreign trade, with its main trading partners for the period (1995-2016). To achieve this objective, the gravity model was adopted using a random effects model. The empirical findings show that Jordan's foreign trade is positively determined by Jordan's RGDP and dummy variable that used to capture the effect of a common border with Jordan. On the other side, distance and similarity index are found to be significant factors in influencing Jordanian foreign trade negatively. Finally, the study found that the RGDP of trade partner and bilateral real exchange rate are not statistically significant.
\end{abstract}

Keywords: foreign trade, gravity model, Jordan, panel data

\section{Introduction}

Foreign trade plays a main role in achieving the economic development and obtaining the requirements of production for countries that suffer from limited natural resources. Also, foreign trade plays a significant role in encouraging investment and opening external markets to the output of small countries. The benefits of foreign trade are not confined to these aspects only, but further it relates to a range of economic, social and political effects that touch the life of the individual and society.

Romer (1990) posits the idea of foreign trade role in economic growth through the role of trade in increasing the specialization of inputs in the production process. Thornton (1996) indicates to the contribution of exports in accelerating economic growth through comparing the growth rates of the exporting countries and non-exporting countries. He pointed out that the countries that export a larger share of their output grow faster than other countries, since the growth in exports stimulate the growth in economy as a whole in the form of technological spillovers and other externalities.

Ramos (2001) summarizes the positive relationship between foreign trade and economic growth in some points. First, the effect of trade multiplier on production and employment. Second, the role of export revenues in financing the payments of importing capital goods which raise the potential output of the economy. Third, the competition in export markets accelerates technical progress in production and lead to economies of scale. On the import side, Mazumdar (2000) considers imports as a channel for domestic firms to access foreign technology. Also, the imports serve as a medium to transfer knowledge, research and development from developed to developing countries.

The role of foreign trade in the economy is not relevant to production side only. The consumption also affected by foreign trade, through the impact of foreign trade on the available alternatives for consumers, price level and the level of welfare for consumers and the society as a whole. Also, the foreign trade effect on the political and cooperative relations between countries.

The growing foreign trade in the last years return to the difference in the level of wages and production costs between countries. Furthermore, inability of some countries to provide some commodities locally. Also, the development in transport and communication sectors played a main role in increasing foreign trade around the world. According to a world trade report (2016) issued by World Trade Organization (WTO), the volume of foreign trade on world level has continued to grow positively since 2010. Despite the slowdown in the growth rate of foreign trade volume in the last four years (2012-2015), the volume of goods and services exports 
doubled in 2015 compared to 2005.

In general, Jordan considers foreign trade as a way to overcome the limited resources problem and as a source to import capital goods which raise its production. Also, the passage Jordanian exports to foreign markets participate in overcoming the problem of the small domestic market, that effect on the investment opportunities in Jordan. Therefore, Jordan undertakes some policies to facilitate trade flow in and out Jordan, such as accession to the World Trade Organization and signed a number of trade agreements with many countries.

The importance of foreign trade and its expected role in the economy opened the way for foreign trade to become one of the research fields for many studies. In order to determine the importance of foreign trade, and how to plan and improve the positive role of foreign trade. consequently, the determinants of foreign trade are one of the topics that have been examined to identify the factors that can affect on foreign trade, and determining the appropriate policy to boost the role of foreign trade in an economy.

The importance of studying the determinants of foreign trade is relevant to the importance of foreign trade in achieving economic development. Therefore, this study aims to examine the determinants of Jordanian foreign trade. And this will help the policy maker to identifying and analysis the variables that can affect positively or negatively on Jordanian foreign trade, in order to enhance the role of foreign trade in the Jordanian economy. To achieve this objective, the study employed cross-sectional data for 22 trade partner with Jordan during the period (1995-2016). These countries were selected because they constitute (73.4\%) of Jordanian foreign trade during the study period.

In order to identify the determinants of Jordanian foreign trade, the rest of this paper is organized as follows: the next section describes a theoretical background for gravity model and literature review related to the subject of study. Section three provides a profile of the commodities traded in Jordan and the major markets for Jordanian foreign trade. Methodology and econometric model are presented in section four. Section five reports the empirical results and discussions. Finally, concluding and policy implications will be presented in the last section.

\section{Theoretical Background and Literature Review}

The gravity model is one of many models that used to identify the determinants of bilateral foreign trade, which was developed during the sixties of the last century to help in explaining the movement of foreign trade. The reason to introduce this model in the theories of foreign trade return to the inability of traditional foreign trade theories to provide a comprehensive explanation to foreign trade flow, Keum (2010) explained that the Ricardo model is suitable for using in interpreting the trade of primary industries or secondary industries that depends on raw materials, while the Hecker Olen model is appropriate for interpreting the trade of industries seeking to reduce costs.

This models omitted the role of distance in determining the flow of foreign trade, which is considered as an essential variable in explaining the movement of foreign trade between countries. The first attempt to introduce this variable into foreign trade studies was the attempt of Isard (1954). The assumption of using the distance factor in the social sciences depends on Newton's Law of gravity in 1687, which states on that there are forces of gravity between any two objects, these forces positively correlate with the size of objects and negatively with the distance between them (Simwaka, 2006).

The basic assumption of the gravity model consistent with the foreign trade theories. Furthermore, the idea of distance is not relevant to the geographical distance between countries only, but also include other factors that can affect on the costs of shipping such as agreements between countries, transport and transaction costs (Bussiere \& Schnatz, 2006). The basic form of the gravity model used in foreign trade depends on the following formula as Morley et al. (2014):

$$
F_{i j}=\beta \frac{\left(G D P_{i}\right)^{\alpha_{1}}\left(G D P_{J}\right)^{\alpha_{2}}}{\left(D_{i S t_{i j}}\right)^{\alpha_{3}}}
$$

Where:

$\left(F_{i j}\right)$ : The volume of foreign trade between the countries $i$ and $j$.

$\left(\mathrm{GDP}_{\mathrm{i}}\right)$ : GDP of country $\mathrm{i}$.

$\left(\mathrm{GDP}_{\mathrm{j}}\right)$ : GDP of country $\mathrm{j}$.

$\left(\right.$ Dist $\left._{\mathrm{ij}}\right)$ : the geographical distance between countries $\mathrm{i}$ and $\mathrm{j}$. 
$\beta, \alpha_{1}, \alpha_{2}$, and $\alpha_{3}$ : the coefficients that will be estimated after converting the mathematical formula to the econometrical form after using the natural logarithm, as in the following model:

Where:

$$
\operatorname{Ln}\left(F_{i j}\right)=\beta+\alpha_{1} \operatorname{Ln}\left(G D P_{i}\right)+\alpha_{2} \operatorname{Ln}\left(G D P_{j}\right)+\alpha_{3} \operatorname{Ln}\left(\text { Dist }_{i j}\right)+\varepsilon_{i j}
$$

Ln: Natural logarithm. And $\varepsilon_{\mathrm{ij}}$ : error term

The determinants of foreign trade using the gravity model are a subject of many applied studies on local and global level. At the local level, Alawin (2009) analyzed Jordan's foreign trade function by using the augmented gravity model, to determine the main variables that affect on the flow of foreign trade in and out Jordan. Carried out that by applying the method of least squares during the period (2000-2005). The main finding of this study and to contrary to previous studies the distance is not significant in determining the volume of trade in Jordan. This result suggests that the development of shipments sector reduces the cost of shipping.

Also, the study pointed that the GDP of trading partners and a common language have a positive impact on the volume of foreign trade. Another study on Jordan, Soufan (2014) identified the major factors that affect on the exports of Jordan by using the gravity model during the period (2003-2012). The results of this study show that: distance, population size and the exchange rate have a significant Impact on the exports of Jordan.

On foreign level, (Martinez-Zarzoso, 2003) applied the gravity model on several areas and economic blocs, includes: the European Union, the North American Free Trade Area, the Caribbean Community, Centro-American common market, and other Mediterranean countries. In this study, Martinez-Zarzoso identify the determinants of trade flow among 47 countries of these groups during the period (1980-1999), the results of his study were as follows: The income elasticities of trading partners are positive and close to unity, geographical distance and population size of exporting country have a negative impact on the volume of trade. In contrast, the coefficient of population size of the importer turned from negative to positive after 1991, and this indicates to the role of scale economies and market-size effects in determining the volume of trade.

Batra (2006), used the gravity model to estimate India's potential trade in (2000), through identifying the determinants of Indian foreign trade using cross-sectional data. The study concluded the importance of geographical distance and the economic size of the trading partner in increasing the volume of trade. Also, the historical and cultural similarity, a common language and borders with the trade partner have a positive role in boosting the volume of bilateral foreign trade. Furthermore, the study used a dummy variable to capture the effect of the absence of ports on the flow of foreign trade, and it found this variable has a negative impact on the volume of foreign trade.

In a study on Nepal, Thapa (2012) used the gravity model to evaluate the determinants of foreign trade between Nepal and 19 major trade partners. The estimated results of Thapa's study show that the trade between Nepal and its major trade partners is positively correlated with the economic size of the countries, while the distance plays a negative role in determining the volume trade, and a per capita income is not statistically significant in this study.

The study of Iqbal and Islam (2014) aims to identify the determinants of foreign trade between Bangladesh and the European union countries during the period (1980-2010). The study found a trade is positively affected by Bangladesh's GDP, and negatively by European Union's GDP and the bilateral real exchange rate. Also, the study used the distance variable as a determinant of foreign trade, but this variable is not statistically significant in Bangladesh's foreign trade function.

The determinants of Cameroon's foreign trade with 28 trade partners from the European union countries are investigated by the study of Doumble and Belinga (2015). The finding of this study reveals that a bilateral trade between Cameroon and its selected trade partners is positively affected by the economic size of the country and per capita income, and negatively affected by a geographical distance of trading partners. On the other side, the dummy variables that used in this study to capture the effect of existing a common official language and the colonial relationship with trading partner are not statistically significant.

\section{Jordanian Foreign Trade}

The last years of the nineteenth century witnessed substantial changes in the world economy, represented by an increasing the degree of economic openness and the dependence of countries on the external sector. This change gave new dimensions for foreign trade that need for more study and analysis to enhance the role of foreign trade in an economy. Consequently, the countries attempt to identify the most important determinants of its foreign trade, in order to determine the appropriate policies that enhance the positive role of foreign trade in the economy. 
Jordan, like other small open countries has some economic problems that can be solved through foreign trade. Therefore, Jordan adopt the policies that aimed to enhance the contribution of foreign trade to the Jordanian economy, these policies played an important role in improving the national exports and opening new channels for Jordanian commodities. On the other side, these policies help Jordan to obtain the requirements of production and essential commodities that can't be produced locally. However, in the last years the Jordanian economy has been affected adversely by political instability in the region. Therefore, the indicators of Jordan's foreign trade have witnessed huge changes in recent years. Figure 1 shows some of these changes in the volume of exports and imports during the study period.

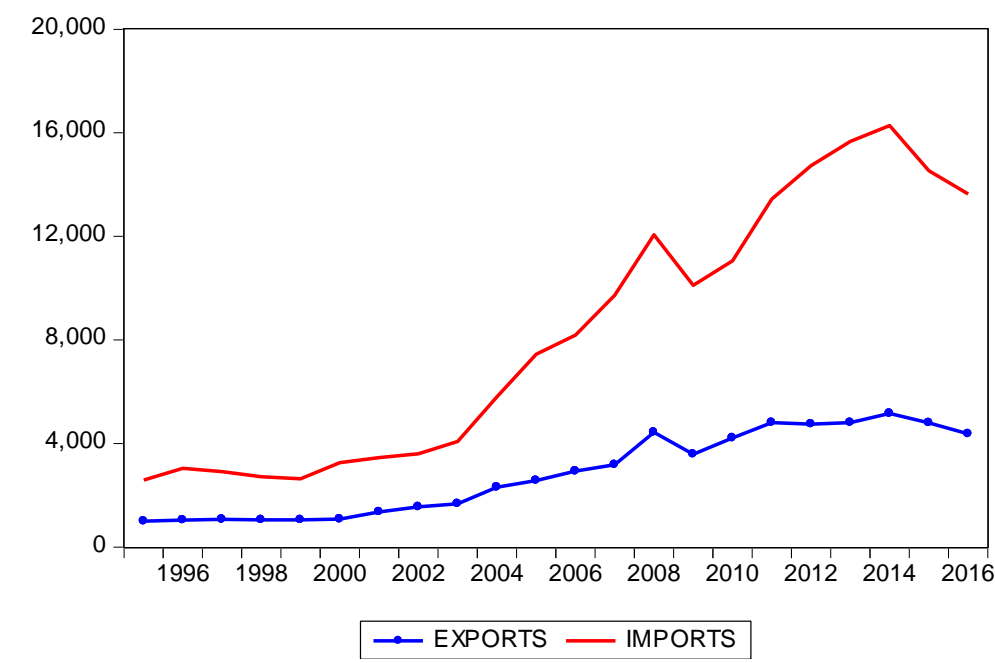

Figure 1. Exports and imports (million JD) during the period (1995-2016)

As noticeably from the previous figure the exports and imports grown significantly since 2004, This growth returns to the procedures taken by the Jordanian government to reduce distortions in the economy, stimulate economic activity, enhance the competitiveness of national industry and create an attractive environment for investment. Also, the performance of the foreign sector in 2004 influenced by the changes in the price of oil and the fluctuations in the exchange rates of major currencies against the Jordanian dinar.

Export and import indicators continued to grow until 2008. In 2009, the Jordanian external sector indicators have affected by reflections of the global financial crisis, where the volume of foreign trade (national exports plus imports) decreased by $17.7 \%$ in 2009 compared to 2008. After this period, foreign trade indicators returned to grow until 2014. In 2014 the volume of trade reaches to a highest value despite a political and social instability in the region. Further, the year 2014 witnessed a clear decline in the trade balance deficit as a result of increasing total exports by $6 \%$ and the decline in the price of oil. After 2014 the volume of trade decrease due to decline in the global demand and decrease in the prices of oil, iron and steel.

The changes in the volume of exports and imports have an impact on the most important indicators of Jordanian foreign trade, which are illustrated in Table 1 . The table shows that there is a chronic deficit in the Jordanian trade balance over the study period, as a result of the difference between the volume of imports and exports. The deficit has increased significantly since 2004 and continue to increase over this period. On the other side, the ratio of trade deficit to gross domestic product (GDP) ranged between $-23.2 \%$ and $-49.2 \%$ during the period of study, with an average of $-34.7 \%$ of GDP.

Table 1 also summarizes the data on the economic openness index (ratio of foreign trade to GDP) which increased significantly during the period 2004-2008, as a result of a significant increase in the volume of exports and imports in this period. The index of openness started to decline beginning in 2012 to reach $65.6 \%$ in 2016. Finally, the exports receipts finance on average $(44.1 \%)$ from import payments based on the data on exports to imports ratio. 
Table 1. Jordan's foreign trade indicators

\begin{tabular}{lcccccc}
\hline Years & $\begin{array}{c}\text { Trade Balance } \\
\text { (million JD) }\end{array}$ & $\begin{array}{c}\text { Trade Deficit } \\
\text { to GDP }\end{array}$ & $\begin{array}{c}\text { Openness } \\
\text { Degree }\end{array}$ & $\begin{array}{c}\text { Exports } \\
\text { Growth }\end{array}$ & $\begin{array}{c}\text { Imports } \\
\text { Growth }\end{array}$ & $\begin{array}{c}\text { Exports to } \\
\text { Imports }\end{array}$ \\
\hline $\mathbf{1 9 9 5}$ & -1349.1 & $-28.6 \%$ & $76.2 \%$ & $26.5 \%$ & $9.6 \%$ & $47.9 \%$ \\
$\mathbf{1 9 9 6}$ & -1755.4 & $-35.2 \%$ & $82.0 \%$ & $3.5 \%$ & $17.5 \%$ & $42.3 \%$ \\
$\mathbf{1 9 9 7}$ & -1606.7 & $-30.9 \%$ & $76.6 \%$ & $2.6 \%$ & $-4.5 \%$ & $44.7 \%$ \\
$\mathbf{1 9 9 8}$ & -1436.5 & $-25.5 \%$ & $66.6 \%$ & $-1.9 \%$ & $-6.7 \%$ & $47.1 \%$ \\
$\mathbf{1 9 9 9}$ & -1336.5 & $-23.2 \%$ & $63.9 \%$ & $0.5 \%$ & $-2.9 \%$ & $49.3 \%$ \\
$\mathbf{2 0 0 0}$ & -1912.8 & $-31.9 \%$ & $72.4 \%$ & $2.8 \%$ & $23.7 \%$ & $41.3 \%$ \\
$\mathbf{2 0 0 1}$ & -1827.0 & $-28.7 \%$ & $75.5 \%$ & $25.1 \%$ & $6.0 \%$ & $47.1 \%$ \\
$\mathbf{2 0 0 2}$ & -1635.2 & $-24.1 \%$ & $75.9 \%$ & $15.1 \%$ & $4.2 \%$ & $54.6 \%$ \\
$\mathbf{2 0 0 3}$ & -1887.1 & $-26.1 \%$ & $79.5 \%$ & $7.6 \%$ & $13.1 \%$ & $53.7 \%$ \\
$\mathbf{2 0 0 4}$ & -3046.2 & $-37.7 \%$ & $100.2 \%$ & $37.7 \%$ & $42.4 \%$ & $47.5 \%$ \\
$\mathbf{2 0 0 5}$ & -4393.3 & $-49.2 \%$ & $112.2 \%$ & $11.4 \%$ & $28.3 \%$ & $41.0 \%$ \\
$\mathbf{2 0 0 6}$ & -4497.8 & $-43.3 \%$ & $107.1 \%$ & $14.0 \%$ & $10.0 \%$ & $45.1 \%$ \\
$\mathbf{2 0 0 7}$ & -5658.6 & $-46.6 \%$ & $106.4 \%$ & $8.7 \%$ & $18.7 \%$ & $41.8 \%$ \\
$\mathbf{2 0 0 8}$ & -6427.9 & $-41.2 \%$ & $105.8 \%$ & $39.2 \%$ & $24.1 \%$ & $46.7 \%$ \\
$\mathbf{2 0 0 9}$ & -5581.3 & $-33.0 \%$ & $80.9 \%$ & $-19.2 \%$ & $-16.2 \%$ & $44.8 \%$ \\
$\mathbf{2 0 1 0}$ & -6060.0 & $-32.3 \%$ & $81.4 \%$ & $17.8 \%$ & $9.3 \%$ & $45.2 \%$ \\
$\mathbf{2 0 1 1}$ & -7755.6 & $-37.9 \%$ & $89.1 \%$ & $14.0 \%$ & $21.6 \%$ & $42.3 \%$ \\
$\mathbf{2 0 1 2}$ & -9134.3 & $-41.6 \%$ & $88.7 \%$ & $-1.2 \%$ & $9.6 \%$ & $38.0 \%$ \\
$\mathbf{2 0 1 3}$ & -10049.3 & $-42.1 \%$ & $85.8 \%$ & $1.2 \%$ & $6.3 \%$ & $35.9 \%$ \\
$\mathbf{2 0 1 4}$ & -10327.0 & $-40.6 \%$ & $84.3 \%$ & $7.4 \%$ & $3.9 \%$ & $36.6 \%$ \\
$\mathbf{2 0 1 5}$ & -8975.8 & $-33.7 \%$ & $72.6 \%$ & $-7.1 \%$ & $-10.7 \%$ & $38.3 \%$ \\
$\mathbf{2 0 1 6}$ & -8305.6 & $-30.3 \%$ & $65.6 \%$ & $-8.9 \%$ & $-6.2 \%$ & $39.1 \%$ \\
\hline
\end{tabular}

Source: estimated by author based on the data of central bank of Jordan.

The geographical distribution of exports and imports indicates that the exports and imports are restricted to geographical concentration. On exports level, the statistics in Table 2 determine the main destinations for Jordanian exports which can be summarized in the following points:

1). Arab countries ranked first in the terms of geographical destination for Jordanian exports, representing about $(50.71 \%)$ of total exports in the last five years.

2). The north American countries ranked as a second main destination for Jordanian exports, including (20.09\%) of total exports.

3). Finally, the non-Arab Asian countries accounted for (20.03\%) of total exports during (2012-2016).

In terms of imports, Table 2 shows that the Jordanian imports come from three main sources:

1). The non-Arab Asian countries accounted for (31.22\%) of total imports in the last five years.

2). Arab countries ranked second in the list of geographical sources for Jordanian imports, including about (28.97\%) of total imports during (2012-2016).

3). Third, the European countries accounted for (26.61\%) of total imports in the last five years.

Table 2. Geographical distributions of Jordan's foreign trade

\begin{tabular}{ccccccc}
\hline \multirow{2}{*}{ Years } & \multicolumn{5}{c}{ Exports } \\
\cline { 2 - 7 } & $\begin{array}{c}\text { Arab } \\
\text { countries }\end{array}$ & $\begin{array}{c}\text { North American Free Trade } \\
\text { Agreement }\end{array}$ & $\begin{array}{c}\text { South American } \\
\text { countries }\end{array}$ & $\begin{array}{c}\text { Non-Arab Asian } \\
\text { countries }\end{array}$ & $\begin{array}{c}\text { European } \\
\text { countries }\end{array}$ & $\begin{array}{c}\text { Other } \\
\text { countries }\end{array}$ \\
\hline $\mathbf{2 0 1 2}$ & $48.57 \%$ & $16.90 \%$ & $0.15 \%$ & $24.19 \%$ & $5.41 \%$ & $4.77 \%$ \\
$\mathbf{2 0 1 3}$ & $53.52 \%$ & $18.26 \%$ & $0.19 \%$ & $18.86 \%$ & $4.06 \%$ & $5.11 \%$ \\
$\mathbf{2 0 1 4}$ & $51.45 \%$ & $18.73 \%$ & $0.24 \%$ & $19.79 \%$ & $4.59 \%$ \\
$\mathbf{2 0 1 5}$ & $50.94 \%$ & $21.71 \%$ & $0.07 \%$ & $20.00 \%$ & $3.03 \%$ \\
$\mathbf{2 0 1 6}$ & $49.08 \%$ & $24.84 \%$ & $0.11 \%$ & $17.30 \%$ & $3.04 \%$ \\
Average & $\mathbf{5 0 . 7 1 \%}$ & $\mathbf{2 0 . 0 9 \%}$ & $\mathbf{0 . 1 5 \%}$ & $\mathbf{2 0 . 0 3 \%}$ & $\mathbf{4 . 0 3 \%}$ & $5.62 \%$ \\
\hline
\end{tabular}




\begin{tabular}{ccccccc}
\hline \multicolumn{5}{c}{ Imports } \\
\hline $\mathbf{2 0 1 2}$ & $35.71 \%$ & $7.08 \%$ & $3.12 \%$ & $28.17 \%$ & $23.94 \%$ & $1.99 \%$ \\
$\mathbf{2 0 1 3}$ & $30.70 \%$ & $6.74 \%$ & $3.37 \%$ & $29.86 \%$ & $27.10 \%$ & $2.24 \%$ \\
$\mathbf{2 0 1 4}$ & $30.03 \%$ & $6.26 \%$ & $3.03 \%$ & $31.33 \%$ & $27.20 \%$ & $2.15 \%$ \\
$\mathbf{2 0 1 5}$ & $25.55 \%$ & $6.98 \%$ & $3.49 \%$ & $33.50 \%$ & $27.09 \%$ \\
$\mathbf{2 0 1 6}$ & $22.85 \%$ & $8.24 \%$ & $3.43 \%$ & $33.26 \%$ & $27.74 \%$ & $4.48 \%$ \\
Average & $\mathbf{2 8 . 9 7 \%}$ & $\mathbf{7 . 0 6 \%}$ & $\mathbf{3 . 2 9 \%}$ & $\mathbf{3 1 . 2 2 \%}$ & $\mathbf{2 6 . 6 1 \%}$ & $\mathbf{2 . 8 5 \%}$ \\
\hline
\end{tabular}

Source: estimated by author based on the data of central bank of Jordan.

Finally, the structure of Jordanian exports and imports is focused in a specific group of commodities. In terms of exports composition we can find that the exports are concentrated in five major groups of commodities, accounted for $53.88 \%$ of the total exports during the last five years of study (2012-2016). These groups include: Clothing by $18.65 \%$, Vegetables, Fruits and Nuts by $10.51 \%$, Pharmaceutical and Pharmaceutical Products by $8.87 \%$, Potash by $8.59 \%$ and Phosphates by $7.25 \%$. These figures reflect the growth of non-traditional exports, and increasing the competitiveness of Jordanian exports in foreign markets.

On imports composition side, we can find that the imports are concentrated in a larger group, including crude oil, transportation and spare parts, textile and its products, iron and steel, Plastics, pharmaceuticals, pharmaceuticals, meat and fish, electrical appliances, clothing, shoes, machinery and equipment used in agriculture, industry and construction sectors. These groups accounted for $57.53 \%$ of the volume of Jordanian imports. Finally, the commodity structure of Jordanian imports indicates that the demand for basic inputs is increased, to meet the needing of domestic industries and the infrastructure improvement light of economic activities growth.

\section{Methodology and Data}

This study aims to identify the determinants of Jordanian foreign trade using the gravity model and a panel data during the period (1995-2016). The data of 22 major trading partners to Jordan are used, these countries constitute more than $73.4 \%$ of Jordanian foreign trade during the study period. In order to achieve this objective, the author applied a modified gravity model, which includes a several variables in equation (2). Therefore, the estimation of gravity model is performed in the following form:

$$
\begin{aligned}
\operatorname{Ln}\left(T_{i j t}\right)= & \beta+\alpha_{1} \operatorname{Ln}\left(G D P_{i t}\right)+\alpha_{2} \operatorname{Ln}\left(G D P_{j t}\right)+\alpha_{3} \operatorname{Ln}\left(\operatorname{Dist}_{i j}\right) \\
& +\alpha_{4} \operatorname{Ln}\left(\operatorname{Re} x_{i j t}\right)+\alpha_{5} \operatorname{Ln}\left(\operatorname{Sim}_{i j t}\right)+\alpha_{6} \operatorname{Dbor}+\varepsilon_{i j t}
\end{aligned}
$$

Where:

$\mathrm{T}_{\mathrm{ij} t}$ : The volume of trade between Jordan and country i during the period $t$, it measured by the sum of exports and imports in real terms and million of USA dollars;

$\mathrm{GDP}_{\mathrm{it}}$ : Gross domestic product of country $\mathrm{i}$ in period $\mathrm{t}$, and at the constant prices in million of USA dollars;

$\mathrm{GDP}_{\mathrm{jt}}$ : Gross domestic product of Jordan in period $\mathrm{t}$, and at the constant prices in million of USA dollars;

Dist $\mathrm{ij}_{\mathrm{j}}$ : the geographical distance between Jordan and countries i.;

Rex $_{\mathrm{ijt}}$ : bilateral real exchange rate between Jordan and country i during the period $\mathrm{t}$. It calculated by multiplied the nominal exchange rate with ratio of country i prices to price level in Jordan.

$\operatorname{Sim}_{\mathrm{ijt}}$ : similirty index measured by the following formula as in Yeshineh (2016):

$$
1-\left(\frac{G D P_{i t}}{G D P_{i t}+G D P_{j t}}\right)^{2}-\left(\frac{G D P_{j t}}{G D P_{i t}+G D P_{j t}}\right)^{2}
$$

Dbor: dummy variable taking the value of unity if a country has a common border with Jordan and zero otherwise countries.

$\beta, \alpha_{1}, \alpha_{2}, \alpha_{3}, \alpha_{4}, \alpha_{5}$, and $\alpha_{6}$ : the coefficients that will be estimated.

Ln: Natural logarithm.

$\varepsilon_{\mathrm{ijt}}$ : error term.

To carry out the estimation of this equation, the data is extracted from various sources such as the Central Bank of Jordan, International Monetary Fund and the following web site: http://ar.distance.to/

\section{Empirical Results}

Previous studies used a Panel data through three alternative models, Pooled model, the fixed effect model and 
the random effect model. And to determine the more appropriate model the studies run some tests. Firstly, the study must examine the univariate characteristics of time series through the stationary test. In panel data, there are many tests that can apply to test the stationary of data. This study run Levin, Lin and Chu method (LLC) to test the null hypothesis of that each individual series contain a unit root against the alternative hypothesis that each series is stationary.

The results of (LLC) test are presented in table (3), which state that the null hypothesis is rejected at 5\% level for all variables. Which means that all variables are stationary and we can go in estimating equation (3).

Table 3. unit root test (Levin, Lin and Chu test)

\begin{tabular}{lccc}
\hline Variable & Statistics & Probability & Observation \\
\hline $\mathbf{L n}\left(\mathbf{T}_{\mathrm{ij}}\right)$ & $-2.19^{*}$ & 0.01 & 418 \\
$\mathbf{L n}\left(\mathbf{R G D P}_{\mathbf{i t}}\right)$ & $-2.47^{*}$ & 0.01 & 413 \\
$\mathbf{L n}\left(\mathbf{R G D P}_{\mathbf{j}}\right)$ & $-6.14^{*}$ & 0.00 & 440 \\
$\mathbf{L n}\left(\mathbf{R e x}_{\mathbf{i j}}\right)$ & $-1.67^{*}$ & 0.05 & 451 \\
$\mathbf{L n}\left(\mathbf{S i m}_{\mathrm{ij}}\right)$ & $-1.97^{*}$ & 0.02 & 442 \\
\hline
\end{tabular}

Note. * significant at $5 \%$ level.

The estimation results of equation (3) are presented in Table (4), where the equation (3) is estimated by three alternative models, pooled, fixed effects and random effects model. Furthermore, the table shows the results of the redundant fixed effects test, Breusch-Pagan test and Hausman test which uses to determine the more appropriate model.

Based on redundant fixed effects test we can reject the null hypothesis of redundant cross-section effect. Therefore, the fixed effects model is more appropriate than pooled model. Further, Breusch-Pagan test indicate that we can reject the null hypothesis of no random effects, then the random effect model is more appropriate than pooled model. Finally, the study performs Hausman test to compare the estimations of the fixed and random effects model, based on this test the random effects model is a more appropriate model.

Table 4. The estimation results

\begin{tabular}{|c|c|c|c|}
\hline Variables & Pooled & Fixed effect model & Random effect model \\
\hline \multirow[t]{2}{*}{$\mathbf{C}$} & -5.57 & -10.05 & -5.68 \\
\hline & $(-6.03)^{*}$ & $(-7.71)^{*}$ & $(-4.71)^{*}$ \\
\hline \multirow[t]{2}{*}{$\log \left(\mathbf{R G D P}_{\mathrm{i}}\right)$} & 0.06 & -0.06 & -0.04 \\
\hline & $(0.76)$ & $(-0.97)$ & $(-0.74)$ \\
\hline \multirow[t]{2}{*}{$\log \left(\right.$ RGDP $\left._{\mathbf{j}}\right)$} & 1.15 & 1.31 & 1.23 \\
\hline & $(10.13)^{*}$ & $(16.19)^{*}$ & $(16.44)^{*}$ \\
\hline \multirow[t]{2}{*}{$\log ($ Dist $)$} & -0.31 & & -0.27 \\
\hline & $(-7.68)^{*}$ & & $(-1.95)^{* *}$ \\
\hline \multirow[t]{2}{*}{$\operatorname{Ln}\left(\operatorname{Rex}_{i j}\right)$} & 0.04 & 0.49 & 0.08 \\
\hline & $(3.24)^{* *}$ & $(2.77)$ & $(1.45)$ \\
\hline \multirow[t]{2}{*}{$\operatorname{Ln}(\operatorname{Sim})$} & -0.5 & -0.86 & -0.6 \\
\hline & $(-6.13)^{*}$ & $(-6.14)^{*}$ & $(-7.24)^{*}$ \\
\hline \multirow[t]{2}{*}{ Dbor } & 1.32 & & 1.26 \\
\hline & $(12.59)^{*}$ & & $(2.81)^{*}$ \\
\hline $\mathbf{R}^{2}$ & 0.55 & 0.84 & 0.46 \\
\hline Adjusted $\mathbf{R}^{2}$ & 0.54 & 0.83 & 0.45 \\
\hline F-statistics & 97.02 & 93.33 & 66.94 \\
\hline Redundant fixed effects test & & $78.25^{*}$ & \\
\hline BP-test & $1892.367 *$ & & \\
\hline Hausman test & & & 6.41 \\
\hline
\end{tabular}

Note. t-statistics in parenthesis; $*$ significant at $1 \% ; * *$ significant at $5 \%$.

The estimation results in table (4) indicate that the coefficients of variables in three alternative models almost have the expected sign, except the coefficient of $\ln \left(\mathrm{GDP}_{\mathrm{i}}\right)$ where it negative and insignificant. Moreover, the 
results of models refer to little variation in the coefficient of variables across models.

The results of the random effects model identify statistically significant determinants of Jordanian foreign trade: RGDP of Jordan, distance, real exchange rate, similarity index and dummy variable. The effects of these variables on foreign trade can be explained as follows: increase in RGDP of Jordan by $1 \%$ will increase trade flow by $1.23 \%$, and the geographical distance has negative impact on Jordanian foreign trade, which mean Jordanian foreign trade related mainly to the countries near to Jordan.

The coefficient of similarity index is negative and statistically significant, suggesting that the Jordanian foreign trade due to differences in technology and with dissimilar economies. Based on previous studies, this coefficient tends to be negative when a country exports agricultural goods or low-skilled commodities and imports manufacturing goods, as in Jordan case.

Moreover, the dummy variable that used to capture the effects of existence a common border with Jordan has a positive statistically significant impact on Jordanian foreign trade. Which means trade partner sharing a common border with Jordan trade $1.26 \%$ more than an otherwise similar partner. On the other side, the RGDP of trade partner and bilateral real exchange rate are statistically insignificant. This result is relevant to the structure of Jordanian foreign trade that is focused on exporting and importing crude materials basically which perfectly inelastic with the price level and the value of RGDP of trade partners.

Finally, the results of the random effects model indicate that 0.46 of the variations in Jordan foreign trade can be explained by the independent variable that employed in this study based on the value of $R^{2}$. Also, the value of F-statistics implies that the independent variables are jointly significant.

\section{Conclusion and Policy Implication}

The Jordanian foreign trade indicators have fluctuated over the last years, due to many reasons that are relevant to Jordan, trade partner or region. It is therefore important to examine the most determinants of Jordanian foreign trade to help in boosting the role of foreign trade in Jordan. To do that, the gravity model is estimated using a random effects model.

The empirical results of the study show that RGDP of Jordan, distance, real exchange rate, similarity index and dummy variable are significant determinants of Jordanian foreign trade, and all variables have the expected sign. On the other side, the RGDP of trade partner and bilateral real exchange rate are statistically insignificant.

The empirical finding can make the following recommendations to policy makers: first, since the distance play a negative role in determining the volume of Jordanian foreign trade, the policy maker should focus on the policies that ensure low transaction costs, through promoting trade within the region. Also, the policy maker must adopt the policies that reduce the cost of shipping through improving the infrastructure for shipments sector and contract a free trade agreements with distant countries.

Second, since there is a positive impact of Jordanian RGDP on foreign trade the policy maker must undertake the policies that promote their economic growth. Finally, based on the data of foreign trade, the Jordanian exports are focused in some commodities and for some destinations. Therefore, the government should encourage the private sector to diversify their products and improving the quality of its products to increase the competitiveness the Jordanian products in foreign markets.

\section{References}

Alawin, M. (2009). Does The Gravity Model Fit Jordan's Trade Pattern? Dirasat. Administrative Sciences, 36(2), 566-576.

Batra, A. (2006). India's Global Trade Potential: The Gravity Model Approach. Global Economic Review, 35, 327-361. https://doi.org/10.1080/12265080600888090

Bussiére, M., \& Schnatz, B. (2006). Evaluating China's Integration in World Trade with a Gravity Model Based Benchmark. European Central Bank Working Paper No.693.

Doumble, E., \& Belinga, T. (2015). A Gravity Model Analysis for Trade between Cameroon and Twenty-Eight European Union Countries. Open Journal of Social Sciences, 3, 114-122. https://doi.org/10.4236/jss.2015.38013

Iqbal, M., \& Islam, A. (2014). Determinants of bilateral trade between Bangladesh and the European Union: Approach of gravity model under the panel data. Issues in Business Management and Economics, 2(5), 87-93.

Isard, W. (1954). Location theory and trade theory: short-run analysis. The Quarterly Journal of Economics, 
68(2), 305-322. https://doi.org/10.2307/1884452

Keum, K. (2010). Tourism Flows and Trade Theory: A panel data analysis with gravity model. The Annals of Regional Science, 44(3), 541-557. https://doi.org/10.1007/s00168-008-0275-2

Martinez-Zarzoso, I. (2003). Gravity model: An application to trade between regional blocs. Atlantic Economic Journal, 31(2), 174-187. https://doi.org/10.1007/BF02319869

Mazumdar, J. (2000). Imported machinery and growth in LDCs. Journal of Development Economics, 65, 209-224. https://doi.org/10.1016/S0304-3878(01)00134-1

Morley, C., Rossello', J., \& Santana-Gallego, M. (2014). Gravity Models for Tourism Demand: Theory and Use. Annals of Tourism Research, 48(1), 1-10. https://doi.org/10.1016/j.annals.2014.05.008

Ramos, F. (2001). Exports, imports, and economic growth in Portugal: Evidence from causality and cointegration analysis. Economic Modelling, 18, 613-623. https://doi.org/10.1016/S0264-9993(00)00055-9

Romer, P. (1990). Endogenous technological change. Journal of Politic Economics, 98, 71-102. https://doi.org/10.1086/261725

Simwaka, K. (2006). Dynamics of Malawi’s Trade Flows: A Gravity Model Approach. Munich Personal RePEc Archive (MPRA) Paper No.1122.

Soufan, T. (2014). Factors that Affect Jordan's Exports during the Period (2003-2012). International Journal of Business and Social Science, 5(6), 115-121.

Thapa, S. (2012). Nepal's Trade Flow: Evidence from Gravity Model. NRB Economic Review, 24(1), 16-27.

Thornton, J. (1996). Cointegration, causality and export-led growth in Mexico. Economics Letters, 50, 413-416. https://doi.org/10.1016/0165-1765(95)00780-6

World trade organization. (2016). World trade report.

Yeshineh, A. (2016). Determinants and Potentials of Foreign Trade in Ethiopia: A Gravity Model Analysis. Munich Personal RePEc Archive Paper No. 74509.

\section{Copyrights}

Copyright for this article is retained by the author(s), with first publication rights granted to the journal.

This is an open-access article distributed under the terms and conditions of the Creative Commons Attribution license (http://creativecommons.org/licenses/by/4.0/). 